\title{
The Pandemic and the Notion of Duties and Responsibilities Under Human Rights
}

\author{
Farid Sufian Shuaib1,* \\ ${ }^{1}$ Ahmad Ibrahim Kulliyyah of Laws, International Islamic University Malaysia \\ *Corresponding author. Email: farid@iium.edu.my
}

\begin{abstract}
During the current COVID-19 pandemic, State authorities prescribe public health measures to reduce the risk or the rate of infection in the community. Such measures impose restrictions on the freedom of movement and how the public conduct their business such as the lock down order, physical distancing, mandate to wear face mask and prohibition of mass gatherings. Such measures invite criticisms and objections from some sections of the society since it transgresses into freedom of individuals. In German and the United States of America for instance, protests were made against the official measures of prescribing wearing of face mask and physical distancing. This paper seeks to examine the question raised under human rights discourse and on the responds of different communities on such restrictive public health measures including the respond of such measures in Malaysia. It is interesting to see the different responds in a society where there is emphasis on communitarian rights as oppose to individual rights.
\end{abstract}

Keywords: pandemic, duties, responsibilities, human rights.

\section{INTRODUCTION}

Coronavirus disease, known as COVID-19, is an infectious disease caused by a newly discovered coronavirus. The virus will affect primarily the respiratory system and infected person experiences mild to moderate respiratory illness and recover without special intervention. However, the elderly and those with underlying medical problems such as cardiovascular disease, diabetes, chronic respiratory disease is more likely to develop serious illness.

The COVID-19 virus was traced to have appeared in Wuhan, China in December 2019. As of $17^{\text {th }}$ October2020 there were $39,196,259$ positive cases of COVID-19 including 1,101,298 death from 235 countries. The COVID-19 virus spreads primarily through droplets of saliva or discharge from the nose when infected person coughs or sneezes. Even though the illness caused by the virus is not necessarily severe, it is highly transmissible and debilitating to the individuals and the community. Thus, the state authorities in all over the world have taken restrictive public health measures to prevent or slow down the transmission in the community, public health measures such as lock down order, physical distancing, mandate to wear face mask and prohibition of mass gatherings are implemented.

Such measures produce different responses from the public. In some countries such as in Malaysia, Japan and China, there are generally high compliance to the instruction given by the state authorities. In other countries, such as the United States of America and German, the public resisted the instruction issued by the state authorities in curtailing the transmission in the community.

\section{RESTRICTIVE PUBLIC HEALTH MEASURES AND THE RESPONDS}

One of the means to reduce the rate of the infection of COVID-19 is for the state to implement public health measures such as physical distancing, wearing of face masks in public places or indoor facilities and stay home order. Such measures are in line with the contemporaneous scientific data in reducing community transmission of COVID-19.

Such public health measures are restrictive to the freedom of individuals. The requirement for physical distancing, in a way, is an affront to the 
freedom to assemble. Depending on the status of the pandemic in the localities, there may be an outright ban to congregate or restriction is imposed on the number of people in a congregation. Districts and countries in Europe, Asia and Americas have imposed such restrictions. Restrictions of travels, including venturing outside homes and in public parks, on the face of it, impede on the rights to movement. Mandating the wearing of face mask covering the nose and mouth is considered an affront to personal liberty since the face itself is considered representing the individuality of the person.

Wide protest ensues the restriction on travel, assembly and instruction to wear face masks. For instance in August 2020, in Berlin, Germany, a massive protest of 18,000 people against the public health measures took place without attendees following the requirement of physical distancing and wearing of face masks in spite of more than 250,000 people were infected by COVID-19 in German. In the United States of America, antimask movement sprung up after the advisory or mandate were given out for the wearing of face masks. Some regarded the instructions as an affront to their personal liberty and the state has no business in regulating their life. Similar protest conducted on 18th October 2020 in London where some carry the placards "My Body My Choice, No to Mandatory Masks".

Although there may be isolated objections against movement restrictions and wearing of face masks in other part of the world, for instance in Asia, but one could not find a massive protest against such public health measures. By and large, the public in Asia complies with the public health advisory and regulation. Wearing of face masks is ubiquitous in countries such as Malaysia, South Korea and Japan. In Malaysia that continue to be under political conflict and uncertainties, mass gathering is not being sought by supporters and detractors of the ruling governments. In contrast, mass protest could be seen in the United States of America against contentious political issues such as the position of women and alleged police brutality some time in spite of prohibition of mass gathering.

It is interesting to consider the different responds towards the decree on public health measures from the people in the North and the South, particularly in Asia. Much of the objections raised against the public health measures are on human rights and freedom.

\section{HUMAN RIGHTS AND LIBERALISM}

An important purpose of the state is to protect the welfare and dignity of the individual and the community. Human dignity could be protected through granting of rights to individuals. Rights refers to legal advantage in respect of claim, privilege, power or immunity [1]. It gives the idea of the ability to make demand from someone or allowance to do something without interference. The first-generation rights (civil and political rights) in particular which could be found in the Universal Declaration of Human Rights (UDHR) emphasises the individual to prosper in a political community by the ability to exert their individuality in their voices and choices. The state is put on guard from restraining the individual's voices and choices. As mentioned by the International Council on Human Rights, "the main purpose of international human rights standards is to protect the individual, usually against the arbitrary exercise of State power".[2]

Although it has been said that human rights as found under the first-generation rights are not wholly averse to incorporating duties, it could not be denied that the emphasis remains on the individuals exercising rights. Underlying this understanding is the concept of liberalism originating from the European Enlightenment of the seventeenth and eighteenth centuries which regards all individuals are equipped with reason and thus are able to make individual decisions.[3]

The counter current to the emphasis of individual rights led some to call for a global ethic that emphasise on responsibility and duty, rather than only favouring individual rights and freedom.[4]. Others stress the need to go beyond seeing governments as the source of threat to human dignity. Fellow men, as individuals and groups have the responsibility and duty to protect others. [5]

We may point to article 29 (1) of the UDHR that shows the incorporation of the concept of duties under human rights. The clause states that 'everyone has duties to the community in which alone the free and full development of his personality is possible'. The drafting history of UDHR does bear out the acknowledgment of the members of the Commission of Human Rights that it is essential to put forward the principle of limited rights and responsibilities to the community and state. 
It would be interesting to put up the conjecture that the emphasis of personal expression and personal freedoms produce the negative responds towards the restrictive public health measures. The right to travel, to mingle freely and to express freely one's individuality produces the objections and mass protests against the constraints put out by the public health measures.

\section{HUMAN RIGHTS AND ASIAN VALUES}

In discussing human rights, the debate on universalism and cultural relativism enters the fray. In the context of Asia, the proponents of Asian values in the 1990's from the like of Mahathir Mohamad (former Prime Minister of Malaysia), Lee Kuan Yew (former Prime Minister of Singapore) and Suharto (former President of Indonesia) propose that there is a set of core values which is distinctively Asian.[6] Since Asian states have diverse history, religious belongings, ethnic groups and cultural experience, it is suspect that one could find one set of Asian values. Be that as it may, one still could argue that one could distil a set of core values that uniquely Asian.

One value that could be found in the Asian society is the communitarian value. Communitarianism is a social philosophy that emphasizes the importance of the society as oppose to the primacy of the individual.[7] In a way it is opposite to liberalism that says good could be determined only by each individual by himself, not by common formulation of the community. In this respect, the state cannot be neutral in setting the common good.

Another aspect communitarian value is the emphasis on duty. In contrast to liberalism where the emphasis is on the negative duty of the state not to interfere with the rights of individuals, communitarian emphasise on the positive duty of the individual to ensure the good of the community.[8] Individuals are responsible to conduct themselves in such a way that would not endanger others or the community in general.

Individual liberalism that underlies the concept of human rights advocates for voluntary transactions and exchanges in the economy with the least use of the coercive power of the state. Communitarian on the hand advocates for the community units such as local communities, volunteers, religious organisations to be involved in ensuring the welfare of the community.[9] In
Malaysia this is found in the concept of gotongroyong of local communities - the cooperative works done by the local communities in helping each other.

The social norms express by Confucianism for instance is communitarian where public interest is place above individual interest.[10] Confucius teaches obligations of individuals and their place the social order. Thus, those who subscribe to the teaching of Confucianism would see themselves as belonging to a family, a community and a country where 'collective spirit' is prioritised. Traditional values of giving respect and cherish the elders, women and children are part of the unique Asian values.[11] The same could be said of Buddhism where the principle of compassion and solidarity call people to help each other to the shared path to salvation.

Although Islam accepts the concepts of individuals as the basis of responsibility and honour, it also at the same time put across the need to act in unison with the community. Islam emphasise the individual responsibility of one action.[12] At the same time Islam regards an individual as a responsible member of the society and responsible for those under his care. [13] Islam thus abhor self-indulged actions that put into perils the community.[14]

The idea of communitarian extolls in this paper is not equivalent to authoritarian communitarian that may disregard altogether the value of individuals and rights. It is noted that there were criticisms of Asian values for instance that it is simply an attempt to justify repressive policies of the government.[15] Others criticise that Asian values are not a concept that could be found on the solid ground, that it is thousand years old teaching not reflecting current thinking.[16] Be that as it may, communitarian attempts to strike a balance between individual rights and the rights of the community and the common good.

We could see that communitarian values are embedded in Asia. In Malaysia for instance, the messages of the authority in imposing restrictive public health measures is for the members of the community to protect each other with the hashtag \#KitaJagaKita.[17] 


\section{SOLIDARITY AGAINST COVID-19 IN MALAYSIA AND ASIAN COUNTRIES}

Analysing the responds to the pandemic by the individuals in the Asian community in general, one could see the acceptance of the primacy of duties and communities. In the messages by the different ministries, the emphasis is on the consequence of actions of the individuals to the vulnerable in the community such as the young, the elderly and the immune compromised. The message given is that an individual may be healthy to withstand the onslaught of the virus to the body but infections from their infected body will harm the vulnerable in the community.

In the United States of America, it was reported that some members of the public and the political elites commented that the high numbers of death of the elderly and those with pre-existing conditions should be expected and should not be given to much attention since they were in their way to die anyway. In the Asian community where the elders are given respects such views would not be accepted as a justification for individuals or the state inaction.

The message given is also to empathise with the front-liners in the health care system; that the nurses and doctors should not be unnecessarily put at risk by actions of individuals who do not adopt good practices to sever the chain of infection in the community. Pictures of health care workers in their full hazmat gears taking a break on the hospital floor highlight the dire state of the health care system.

In the West, one could read retort that it is the job of nurses and doctors to take care of patients and thus they should not expect to gain sympathy in doing the job that they are being paid. Such a perspective is a non-starter in Asia since the emphasis is about the vulnerability of a part of the community - namely the health care workers - may without doubt affect the welfare of the whole community.

\section{CONCLUDING REMARKS}

Some view that individual autonomy is too ingrained in the West that it could not be disconnect from the individual even while facing a pandemic that requires restrictive public health measures. Individual liberalism that underpins the human rights in the West bring about mass resistance to instruction that interfere with individual rights of movement, assembly and self-expression.

In contrast, social solidarity is thus a value that helps the countries in Asia to ward off, to a certain degree, the community transmission of the virus. The communitarian value that is embedded in Asia produce responses in the community that consider duties and responsibilities to each other more important than individual rights while fighting the COVID-19 pandemic. The pandemic highlights issues that already exist in society. It brings into focus not something that do not exist but something that is already there. In this context we could ponder whether the debate about Asian value in discussing human rights has always has its legitimacy as accentuated by COVID-19 pandemic. [18]

\section{REFERENCES}

[1] Wesley Newcomb Hohfeld, "Fundamental Legal Conceptions as Applied in Judicial Reasoning” (1917) Yale Law Journal 710, at 717.

[2] International Council on Human Rights Policy, Taking Duties Seriously: Individual Duties in International Human Rights Law, Versoix: International Council on Human Rights Policy, 1999.

[3] Peter O'Brien, The Muslim Question in Europe: Political Controversies and Public Philosophies, Philadelphia: Temple University Press, 2016.

[4] Parliament of World's Religions, Declaration of a Global Ethic, Chicago: Parliament of the World's Religions, 1993.

[5] Commission on Global Governance, Our Global Neighborhood, 1995.

[6] Farid Sufian Shuaib, “Embracing International Human Rights Law: The Malaysian Experience in Navigating the Dual Quality of International Law" (2019) 27:2 IIUM Law Journal 265.

[7] The Encyclopedia of Political Thought, John Wiley \& Sons, 2015.

[8] Michael Freeden, "Human Rights and Welfare: A Communitarian View" (1990) 100:3 Ethics 489.

[9] Amit Etzioni, "Communitarianism revisited" (2014) 19:3 Journal of Political Ideologies 241. [10] Michael D Barr, "Lee Kuan Yew and the 'Asian Values’ Debate” (2000) 24 Asian Stud Rev 309. 
[10] Michael D Barr, "Lee Kuan Yew and the 'Asian Values' Debate" (2000) 24 Asian Stud Rev 309.

[11] Ngo TM Huong, Vu Cong Giao \& Nguyen Minh Tam, "Asian Values and Human Rights: A Vietnamese Perspective" (2018) 2:1 Journal of Southeast Asian Human Rights 302.

[12] The Quran (6:164) "Say: Shall I seek another than Allah for Lord, when He is Lord of all things? Each soul earneth only on its own account, nor doth any laden bear another's load. Then unto your Lord is your return and He will tell you that wherein ye differed."

[13] The Quran (49:13) "O mankind! Lo! We have created you male and female, and have made you nations and tribes that ye may know one another. Lo! the noblest of you, in the sight of Allah, is the best in conduct. Lo! Allah is Knower, Aware." Abdullah ibn Umar reported: The Messenger of Allah, peace and blessings be upon him, said, "Every one of you is a shepherd and is responsible for his flock. The leader of people is a guardian and is responsible for his subjects. A man is the guardian of his family and he is responsible for them. A woman is the guardian of her husband's home and his children and she is responsible for them. The servant of a man is a guardian of the property of his master and he is responsible for it. No doubt, every one of you is a shepherd and is responsible for his flock." (Sahih al Bukhari 6719; Sahih Muslim 1829).

[14] The Quran (66:6) “O ye who believe! Ward off from yourselves and your families a Fire whereof the fuel is men and stones, over which are set angels strong, severe, who resist not Allah in that which He commandeth them, but do that which they are commanded."

[15] Xiaorong Li, "'Asian Values' and the Universality of Human Rights" (1996) 2 Report from the Institute for Philosophy and Public Policy 16.

[16] S Tay, "Human Rights, Culture and the Singapore Example" (1996) 41 McGill Law Journal 743.

[17] The hashtag could be loosely translated as \#WeProtectEachOther.

[18] See for instance Farid Sufian Shuaib, "Administration of Islamic Law and Human Rights:
The Basis and Its Trajectory in Malaysia” (2018) Al Jamiah: Journal of Islamic Studies 281. 